\title{
Complementary apologetics: An attempt for the integration of apologetic schools
}

\begin{tabular}{|c|c|}
\hline $\begin{array}{l}\text { Author: } \\
\text { Willem van VI }\end{array}$ & tuin ${ }^{1,2,3}$ \\
\hline $\begin{array}{l}\text { Affiliations: } \\
{ }^{1} \text { Department } \\
\text { and Spiritualit } \\
\text { Protestantism } \\
\text { South Africa }\end{array}$ & $\begin{array}{l}\text { f Theology } \\
\text { y of Reformed } \\
\text { VU-University, }\end{array}$ \\
\hline $\begin{array}{l}{ }^{2} \text { Director Jona } \\
\text { Centre Benelu } \\
\text { Netherlands }\end{array}$ & $\begin{array}{l}\text { than Edwards } \\
x, \text { the }\end{array}$ \\
\hline $\begin{array}{l}{ }^{3} \text { Research Fell } \\
\text { University of } t \\
\text { South Africa }\end{array}$ & $\begin{array}{l}\text { ow at the } \\
\text { he Free State, }\end{array}$ \\
\hline $\begin{array}{l}\text { Correspondin } \\
\text { email: } \\
\text { Willem van VI } \\
\text { w.van.vlastuin }\end{array}$ & $\begin{array}{l}\text { g author and } \\
\text { astuin } \\
\text { @vu.nl }\end{array}$ \\
\hline $\begin{array}{l}\text { Dates: } \\
\text { Received: } 10 \\
\text { Accepted: } 14 \\
\text { Published: } 18\end{array}$ & $\begin{array}{l}\text { ct. } 2014 \\
\text { Muly } 2015 \\
\text { Mar. } 2016\end{array}$ \\
\hline $\begin{array}{l}\text { How to cite th } \\
\text { Van Vlastuin, } \\
\text { 'Complement } \\
\text { An attempt fo } \\
\text { integration of } \\
\text { schools', In die } \\
\text { Art. \#1890, } 9 \\
\text { dx.doi.org/10. } \\
\text { v50i1.1890 }\end{array}$ & $\begin{array}{l}\text { is article: } \\
\text { N., 2016, } \\
\text { ary apologetics: } \\
\text { r the } \\
\text { apologetic } \\
\text { Skriflig 50(1), } \\
\text { oages. http:// } \\
\text { 4102/ids. }\end{array}$ \\
\hline $\begin{array}{l}\text { Copyright: } \\
\text { (c) 2016. The A } \\
\text { Licensee: AOS } \\
\text { licensed unde } \\
\text { Commons Att } \\
\text { License. }\end{array}$ & $\begin{array}{l}\text { uthors. } \\
\text { S. This work is } \\
\text { the Creative } \\
\text { ibution }\end{array}$ \\
\hline Read online: & \\
\hline 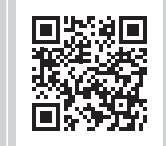 & $\begin{array}{l}\text { Scan this QR } \\
\text { code with your } \\
\text { smart phone or } \\
\text { mobile device } \\
\text { to read online. }\end{array}$ \\
\hline
\end{tabular}

\section{Author:}

Affiliations:

${ }^{1}$ Department of Theology

Protestantism, VU-University,

${ }^{2}$ Director Jonathan Edwards Centre Benelux, the

${ }^{3}$ Research Fellow at the University of the Free State,

email:

Willem van Vlastuin

Dates:

Received: 10 Oct. 2014

Accepted: 14 July 2015

How to cite this article:

Van Vlastuin, W., 2016

Complementary apologetics:

integration of apologetic

Art. \#1890, 9 pages. http://

dx.doi.org/10.4102/ids.

(apyright:

Licensee: AOSIS. This work is licensed under the Creative

Commons Attribution

License.
Within Christian apologetics several schools of thought exist. This article is firstly an attempt to come to a classification of these different schools. Next, the agreements and disagreements between these schools are investigated. It appears that despite the differences there are several common convictions between the several apologetic approaches, namely 'knowing as basis for showing', and 'faith seeks understanding'. These common convictions appear to be fundamental if compared with the differences. The third part of this article explores the arguments for an integration of the different approaches. However, the concept of a strict integration will be problematic, and this leads in the final part to a proposal. The proposal is for a complementary model of concentric circles, starting with the convictions of the heart in the centre in fideism and presuppositionalism, continuing with apologetics which refer to the human mind in classical apologetics and culminating in apologetics that refer to senses in evidentialism.

\section{Introduction}

This article does not deal with apologetics within Christian churches, but with the discourse between belief and unbelief. Within Christian apologetics one finds several streams or schools of thought such as classical apologetics, evidentialism, presuppositionalism and fideism. The different schools sometimes give the impression that their approach is exclusive with respect to other schools. Searching these different apologetic schools, however, gave me the impression that it might be possible to unite these different approaches into one integrated model. Kenneth D. Boa and Robert M. Bowman Jr. (2006:425-523) have investigated the possibilities for such integration. In this article I would like to continue this line of research and propose a model of complementary apologetics instead of a concept of integration.

Firstly, I make some remarks about the classification of the different apologetic schools and roughly sketch some characteristic differences. Secondly, I look for the common convictions in the diverse streams. In the third place I describe some motives for an integration of the different apologetic models. These investigations lead - lastly - to a proposal of a complementary concept of apologetics.

\section{Classification of apologetic schools}

If these schools of thought are classified from the analytical criterion of epistemology, it leads to a classification of three apologetic schools (cf. Boa \& Bowman 2006; Lewis 1976; Ramm 1962). This division tends to appeal to God's truth derived either through existential encounter, natural theology and human reason, or God's direct revelation. This approach can be refined by the subdivision of the second school into classical apologetics and evidentialism, whilst the third school is also sub-divided into presuppositionalism and reformed apologetics.

In 1999 Norman Geisler (1999:41-44) formulated an alternative approach. On the one hand he dissociates himself from a profound logical breakdown into various categories, on the other hand he recognises that different apologetic methods mutually overlap. He came to a subdivision into five categories, namely classical apologetics, evidentialism, historical apologetics, experiential apologetics and presuppositionalism. S.B. Cowan (2000:15-20) distanced himself from an analytical approach. In his work one finds a synthetic format to categorise apologetic methods. Striking enough, this synthetic format leads to a similarity in the distribution of apologetic categories, namely the classical method, evidentialism, the cumulative case method, presuppositionalism, and reformed apologetics. The synthetic format of categorising apologetic methods has the advantage that other methods can be added without damage to the central perspective. 
In this article the choice has been made to divide the apologetic schools from a synthetic perspective in classical apologetics, evidentialism, revelational apologetics (including presuppositionalism and reformed apologetics) and fideism. ${ }^{1}$ The characteristic differences between these apologetical schools can be mapped in a general way. Classic apologetics emphasises reason, evidentialism emphasises facts, revelational apologetics God's revelation, whilst fideism stresses personal faith. Classical apologetics is centred around the reasonable structure of reality; evidentialism shows that faith suits a reasonable worldview, and that from a scientific worldview sufficient arguments for the Christian faith can be given; revelational apologetics reasons from Scripture; whilst the fideist testifies from his personal relationship with Jesus. Whilst apologetics for the classical apologist functions as the prolegomena for theology; the evidentialist will use apologetics in a polemical way; for the revelational apologist theology and apology belong together; and the fideist has less interest in a completed theological system.

These differences appear in several practical situations and in the attitude towards different disciplines. It is not surprising that Roman Catholic apologists use classical apologetics. Revelational apologists can be of a reformed conviction. Fideism is used by protestants who dislike liberal or orthodox systems of thinking.

A comparable division can be made in relation to philosophy and science. Classical apologists are usually positively oriented towards philosophy and science, whilst fideists are characterised by a critical and detached attitude. Revelational apologists accept philosophy and science, but they employ their own Christian philosophical and scientific system, because they are critical towards secular science. Evidentialists are often less philosophical, but they try to integrate faith and science.

With respect to Scripture the following conclusions can be made. Revelational apologists understand Scripture as authoritative concerning the issues of faith and science. Evidentialists seek to prove the historical truths of Scripture and to refer to fulfilled prophecies. Fideists see Scripture often as a witness of God's acts in which the Self-revelation of God is most important and in which the historical reliability can be relativised.

When it comes to the pressing question of evil in history, the revelational apologist will stress God's sovereignty, the evidentialist will wonder whether the amount of evil can be reconciled with God's goodness, the classical apologist argues that God has reasons to accept evil in his creation, whilst the fideist witnesses of his hope in God despite all the evil in history.

1.It would also be possible to plead for orthopraxic apologetics, but in the argument of this article it would not make a significant diffence. Or but in the argument is a is a way of theology of retrieval (cf. Webster 2007:583-599). The actuality of orthopraxic apologetics is also given by the fact that the intellectual structure of the Enlighenment are fading away and do not feed the existential need of our culture (cf. Van den Toren 2011:xi, 2, 4, 10, 35-92).

\section{What apologetic schools have in common}

After sketching the characteristic differences between the different apologetic methods, in this section I will take the opposite direction and explore those convictions which are common in the different apologetic approaches.

\section{'Knowing' as basis for 'showing'}

Every Christian apologist will agree that 'showing' the truth of Christian faith emanates from 'knowing' (Craig 2000:38). Christians use apologetics because they are personally assured of the existence of God and Christ by the witness of the Holy Spirit in their hearts. The personal encounter with the triune God gives the deepest motive to share the gospel with other people that they may participate in the same love, redemption and trust. Every representative of a different apologetic school is convinced that nobody has apologetic motives and abilities without personal faith and personal conviction. Ultimately, apologetics emanates from the communion with God and can only be practiced in the power of the Holy Spirit. In the apologetic discourse it is not important that one succeed by the power of your arguments, but that the unbeliever is won for God and his service. Practical apologetics must be full of prayer and be characterised by heartfelt compassion for one's fellow human beings.

Therefore, the emphasis on a personal relationship with Christ in fideism is not unfamiliar to the representatives of other apologetic schools. This accent is evident in revelational apologetics. In revelational apologetics personal faith functions as an important pivot point of the worldview. This pivot point is so important in presuppositionalism that it can be said that the unbeliever practices science in a different way.

Classical apologists and evidentialists acknowledge the difference between 'showing' and 'knowing'. With this distinction they emphasise that - despite the common ground of reason - the unbeliever thinks on a different wavelength than the believer. Not only the revelational apologist, but also the classical apologist acknowledge the difference between 'inside internal' and 'outside external' faith. There is a difference in the issue as to how to reach the unbeliever, but there is no difference about the question whether believers operate in another dimension than the unbeliever. Despite the common ground between believers and unbelievers, classical apologists acknowledge that reason does not give direct access to God. The classical apologist, the revelational apologist, and the fideist underline that one does not come to real knowledge and assurance of God without the witness of the Holy Spirit. Implicitly it looks as if the fideist blames the classical apologist that he understands faith within the realms of reason, but this reproach is unjustified. Both the fideist and the classical apologist are convinced that natural human beings do not understand the things of the Spirit of God (1 Cor 2:14). 


\section{Faith more than reason}

Representatives of different apologetic schools have in common the conviction that faith is more than reason. Classical apologists who stress most the use of reasonable arguments do not mean that mysteries such as the trinity, the incarnation or reconciliation can be made understandable for the human mind. The use of reason in classical apologetics is limited to the notion of the existence of God, but is not used to explain God, the knowledge of God and the relation with God.

Because the 'distance' between classical apologetics and fideism is the biggest, I argue about these two apologetic schools. The difference between fideism and classical apologetics does not concern the question whether God and the knowledge of him is within the reach of reason. Concerning God and the knowledge of God, both classical apologists and fideists deny the magisterial use of reason in which reason stands over and above the Word of God as a magistrate to judge the content of God's revelation. ${ }^{2}$

An example of this denial is to be found with Martin Luther. In 1517 he held the Disputatio contra scholasticum theologiam [Dispute against scholastic theology]. ${ }^{3}$ In thesis 45 Luther states that it is heresy that a theologian without logics is heresy. In the Disputation Heidelbergae habita [Dispute at Heidelberg] in 1518 Luther confirms his conviction of the uselessness of philosophy and reason in theology. ${ }^{4}$ Luther wants to stress that immanent human reason cannot understand the transcendent reality of God and has no access to the heart of the gospel.

This did not imply that Luther denied every use of reason. It is remarkable that Luther who supplied the ingredients for fideism acknowledged that natural reason was conscious of God, his justice and his mercy, however, this natural knowledge of God does not know what God thinks of us or how God saves us. ${ }^{5}$ Luther denied the magister function or reason, namely the autonomy of reason over and against God's revelation.

Also for believers Luther acknowledged a certain use of reason. In De Servo Arbitrio [The bondage of will] the reformer accuses Erasmus of not thinking through the revelation of God to come to a systematic and unambiguous understanding of Scripture. ${ }^{6}$ This can be called a ministerial use of reason, meaning that reason is under the guidance of Word and Spirit. The classic principle of Fides quaerens intellectum [Faith seeks understanding] can be recognised here. Also the classic

2.W.L. Craig (2000:36-37) refers to tuther for the distinction between magisterial and ministerial use of reason. A comparable approach is to be found in Blaise Pascal. His concept is better described as anti-rationalism than as irrationalism (Edgar 2003:14). Pascal spoke about the 'logic of the heart' as reaction against the rationalistic overestimation of human reason (Peters 2009:164).

3.Luther (WA = Weimarer Ausgabe of Luthers Werke 1, 224-228).

4.Luther (WA 1, 353-365).

5.Luther remarked this on Jonah 1:5 (WA 19, 206-208) and Galathians 4:8-9 (WA 40, 606-608).

6.Luther (WA 18, 606-609, 667-671, 720-722). notion that the finite cannot comprehend the infinite is recognisable in this approach. This means that human beings can have true knowledge of God and can recognise what is true about God and what is false, without comprehending God as God.

The difference between fideism and classic apologetics does not concern the issue of whether human beings can embrace the gospel of Jesus Christ by reason. Both fideism and classic apologetics acknowledge the limits of natural reason with respect to the heart of the gospel. The negative attitude of fideism with respect to human reasons seems to be a great contradiction with classical apologetics, but looking deeper into this attitude it appears that both schools acknowledge the limits of reason. As fideism has possibilities to use the minister-function (in contrast to the magister-function) of reason with respect to faith, it appears that fideism does not speak merely negatively about the use of reason, but it considers reason relatively unusable in matters of faith. As fideism at the same time is able to honor the use of reason in the unbelievers' acknowledgement of the existence of God, it appears that the distance between fideism and classical apologetics is not as big as it appears. The great difference in the attitude towards reason has more to do with the object upon which one is focused than with the difference in the appreciation of reason as such. Whilst fideism has the content of the gospel as its object of consideration and classical apologetics the existence of God as object, it is understandable that both schools speak in a different way about reason. Whilst classic apologetics is committed to a reasonable discourse on the existence of God, fideism does not see the usefulness of such a contact. This means that the difference in judgement about reason concerns more the apologetic approach as such than the judgement about the possibilities of reason as such.

\section{Motives for integration of apologetic schools}

There are different motivations to achieve an integration of apologetic approaches. In this part of the article I will deal with the theological motivation, the historical motivation and the practical motivation and end with a conclusion.

\section{Theological motivation}

Believers live in spiritual communion with Christ. ${ }^{7}$ In this context it should be considered that Christ is not only the Mediator of redemption, but also the Mediator of creation. There are several notions in Scripture which show the relation between Christ and creation (cf. Wyatt 1996:55-123). ${ }^{8}$ This means that redemption in Christ cannot be isolated from the whole of created reality. It is significant that the views of Plato could have been used by Paul (cf. Van Kooten 2008).

7.There is a 'revival' of the concept of unio mystica (Canlis 2010; Horton 2007; Todd Billings 2005; 2008; 2011).

8.John 1:3, 4, 9; Colossians 1:15-20; Hebrews 1:1-2. 
However, there are several possible explanations - it alludes to the light of Christ that shines on every creature in the world. There are reasons to assume that the growing corn, the love in marriages and the results at universities have to do with the work of Christ. This implies that one should not start your reflections in human beings, their belief or their unbelief, but in the reality of God in Christ.

One comes to the same basic patterns if you think from the perspective of creation, sin, redemption and recreation. In recreation the old creation is not discarded, but the old creation is transformed into the new creation. The new creation is fuller and richer than the old creation, but there is not a complete discontinuity. In God's future a spiritual body will be raised on the day of resurrection. Corporeality is a guarantee for continuity, whilst the spiritual character of the body implies discontinuity. These notions show one that this creation is destined for recreation. Despite sin God will achieve his aim with his creation.

The basic patterns of creations are also fundamental. Despite sin these basic patterns are recognisable, so that one does not live in a house of ghosts with daily unexpected and unwanted surprises. That there are many patterns in creation and logic is certainly true. This pleads for an ontological continuity before and after the fall into sin. This view is the source of the argument that God is not far from the unbeliever ${ }^{9}$ and that believers should therefore not keep themselves separate from them. Believers and unbelievers move in the same ontological reality which reminds one of the Creator and the Recreator. It is striking that atheist unconsciousness is oriented towards the order of God in creation.

Revelational apologetics and fideism remind us that creation and redemption cannot be isolated of each other. At the same time it should be pointed out that it is in accordance with Scripture to distinguish creation and recreation. The first message of Scripture is not to call human beings to faith, but to confront them with God. Next follows the necessity of reconciliation with Christ. A striking example is found in the strategy of the apostle Paul. Whilst he starts his message in the synagogues with the message about the Messiah, towards unbelievers he begins his message with God and creation. ${ }^{10}$ These considerations imply that for the present the Christian faith should be considered in two stages.

There is also another view that pleads for the integration of apologetic methods. God starts a personal relationship with his sinful creatures. At the same time he remains the Creator who gives norms for human life and teaches the truth about himself, human beings, creation and history. There are good reasons to dismiss deism. God does not remain at a distance, but he is actively involved in his care for creation. The aspect of the personal relationship is present in fideism. The right of classical apologetics and evidentialism is to be found in their presentation of God's order in the whole of creation, whilst

\section{Acts $17: 27$.}

10.Compare Acts $14: 15-16$ and $17: 24-28$. revelational apologetic asserts the message of Scripture that reveals the meaning of creation. The different ways in which one stand in relation to God justifies different approaches of apologetics. Since the one God is central, there is no reason to separate and isolate the different apologetic approaches from one other. Separating apologetic schools would imply that the different relations with God are made absolute.

Finally, there is an argument from anthropology to defend the unity of the different apologetic approaches. Human beings are intelligent beings. There are reasons to join this anthropological notion in classical apologetic and evidentialism. The intellectual orientation of revelational apologetics does justice to this dimension of Christian life. Revelational apologetic appeals rightly to God's transcendent revelation, whilst evidentialism starts with the immanent reality of God. Beside the human intellect one should also speak about human will, human affections and human intuition. This is the right of fideism.

It can also be said that the Holy Spirit effectively influences the different dimensions of the human mind. By the Spirit the human mind is enlightened so that the same facts receive another meaning. The Word of God becomes the great framework of interpretation of human life and human history. By the Spirit human beings become very willing to be led by the Word and Spirit. These notions underline the desirability of integrated apologetics.

\section{Historical motivation}

Classifying the different apologetic schools makes clear that apologists in history cannot be easily divided. Augustine can be understood as the precursor of both classical apologetics and revelational apologetics (Boa \& Bowman 2006:15-17). But because of Augustine's distinction between sapientia [wisdom] and scientia [science], it can also be argued that fideism has roots in the thinking of the church father. Aquino is seen as the precursor of classical apologetics and evidentialism (2006:19-20). Because of the use of deductive logic in the ontological proof of God, Anselm is classified as a classical apologist, however, Karl Barth (1960:146) has argued that Anselm developed his ontological proof from faith and therefore cannot be classified as a classical apologist. Revelational apologists refer to John Calvin, but it is undeniable that in his thought also aspects of classical apologetics can be found (Boa \& Bowman 2006:221-227). Pascal can be seen as an early representative of fideism, but in his work aspects of evidentialism are also to be found (2006:242-245). Despite many attempts it has been impossible to classify C.S. Lewis as a representative of a certain apologetic school.

The outcome of this search makes clear that the division into several apologetic methods is more idealistic than realistic. To get a clear view of a certain apologetic approach it is good to concentrate on the ideal type of a school, but at the same time it is necessary to acknowledge that the apologetic reality is more complex that the addition of several schools. Apologists can use 
several apologetic methods to share the message of the Bible. It is logical to assume that unbelievers differ. One unbeliever is more receptive to argument $a$, whilst another unbeliever is more receptive to the method of school $b$. Personality, context and culture, education and experience are decisive for the most effective approach. In one conversation logic is important, whilst in another apologetic discourse personal witness is more effective. It is possible that the third unbeliever as a deep thinker is willing to think about the philosophical presuppositions of science. If one's neighbour has lost his daughter through an accident it is not suitable to start an intellectual debate, but it seems much better to give a personal testimony of God's comforts. In an apologetic conversation with Dawkins (2006:169-176), it is unimaginable not to speak about the presuppositions of empiricism, however, it is also imaginable that he is reached by the cosmological proof in the way of classical apologetics if he speaks so easy about multiversa and an endless repetition of evolutionary processes presupposes.

These considerations support the plea for a holistic apologetic approach in which the instruments and the insights of the different apologetic methods are employed. The specialism of the different approaches has improved the quality of the tools, but this increase should be without profit if every apologetic specialisation would isolate itself from the other approaches.

John Frame (1987:73-75) offers instruments which are useful for the integration of apologetic methods. In his epistemology he distinguishes between the existential, the situational and the normative perspective. ${ }^{11}$ He clarifies that subjectivism is the result of absolutising the existential perspective (of fideism), empirism is the fruit of absolutising the scientific approach (of evidentialism) and rationalism is the effect of absolutising logic (in classical apologetics). The triangular approach of Frame shows that every apologetic approach has its own value, but that not any approach can be absolutised.

\section{Pragmatic motives}

There are also pragmatic motives to plead for a holistic integration of apologetic methods. In such a holistic approach the apologist can make use of several apologetic insights and instruments.

The basic use of human intellect cannot be missing in an apologetic debate. A basic instrument in classical apologetics is the use of logic. The law of non-contradiction is fundamental for the whole of life and all human conversation. The general use of intellect is also relevant in relation to the classic proofs for God's existence. These proofs are in the strict sense of the word no proofs, but confirmations for faith. In the culture of the Corpus Christianum these proofs functioned more as a confirmation of faith than as a proof for faith for atheistic people. From the point of view of the apologist these proofs can strengthen the authority of the witness towards the unbeliever and break through irrational prejudices. Also epistemology. Elsewhere Frame (1994) elaborates this perspective for apologetics. today there are arguments to show that it is not unreasonable to be a Christian.

Evidentialism has much material to speak about the reliability of Scripture and historical witness concerning Christ's resurrection. In Scripture the historic character of certain facts are referred to on several occasions. John refers to the miracles of Jesus, whilst Luke assures us that he had done historical research. ${ }^{12}$ This suggests that Christianity is open for historical verification. In the apostolic discourse it can be argued that the witness of Scripture fits best with historical facts. Therefore the historical facts of the history of salvation can serve as a confirmation for faith in God. For the believer these data are confirmations of faith; for the unbeliever these data are confirmations of a witness or an argument.

Revelational apologetic is correct when it argues that people do not come to faith by the proofs of evidentialism, but this truth cannot lead to the conclusion that historical proofs are contrary the transcendent truth of Christian faith. Revelational apologetics is helpful to give consciousness of the Christian framework of interpretation, to elaborate on it and to confront the unbeliever with his (unconscious) interpretative framework of life. It is the great merit of revelational apologetic that it has clarified that neutrality does not exist. Furthermore it has good evidence to show that not all things can be proved in an academic way but that one starts with the truth of it. In this way room for the Christian faith can be created. If it is possible there can be a deep apologetic contact about the presuppositions in which the Christian shows what the consequences are of the unbeliever's presuppositions.

However, it remains formal if this is the only thing that can be interchanged with the unbeliever. Scripture teaches that Christians can refer to historical events to fill the Christian scheme of interpretation. So the non-Christian can see that his interpretative framework is a framework of belief, namely unbelief, and that these facts undermine his framework of interpretation.

Fideism shows that a Christian does not speak about theoretical facts, but that it is existential for him that he accepts the consequences of his worldview. These are moments in which unbelievers can see the power of faith in human life.

These approaches do not exclude each other, but they strengthen each other as several ropes tie a ship to the harbour. Tertullian used in his Apologeticum the context of a court. ${ }^{13}$ In a court arguments and proofs are given to understand the accusations in another context and to plead the innocence

\section{John 20:30-32; cf. also tuke 1:1-4.}

13.Tertullian's writings are edited in volumes 1-2 of the Patrologia Latina and modern texts exist in the Corpus Christianorum Latinorum. English translations of all Tertullian's works can be found in Ante-Nicene Christian Library, vol. 3-4; of all Tertullian's works can be found in Ante-Nicene Christian Library, vol. 3-4;
Apologeticus is to be found in volume 3 . Tertullian is today still studied (Barnes 1985; Bray 1979; Daniel 2010; Dunn 2005). 
of the accused. It is possible that one argument is not sufficient for the acquittal of the accused. But a combination of arguments makes it much more convincing for the judge that the accused is innocent. Whilst the Christian faith is accused of unreasonableness, arrogance, of being a fountain of violence and unscientific attitudes, Christians can defend themselves with several arguments to refute and contradict these accusations. That is the negative side of apologetics. The positive side is that in the removal of the false accusations the case of Christianity can be pleaded in a positive way.

\section{Evaluation of motives for integration}

Finally it will be considered that a certain integration of several apologetic methods does do justice to the reality of the Christian life. Personal faith is the deepest motivation for apologetics. In the personal relationship with Jesus love is born to win others for the gospel. It is conceivable that the personal life of the believer is the occasion of coming to a deeper conversation about reality.

If Christians are asked to give an account of their faith, they can testify about personal faith. Therein they can speak about the meaning of Jesus Christ and of the Trinity. If Christians get critical questions, there are few possibilities of explaining the content of faith in the cross and in the triune God. In that case the Christian cannot do anything but defend faith de iure, because it is the foundation of life. The writings or arguments of Van Til can be used to clarify that also the unbeliever has his presuppositions. This implies that the Christian faith is taken away from the dock and it is put beside other frameworks.

The next step is to show that the Christian framework is true. In this way the de facto objections against the Christian faith can be dealt with. One can speak of the facts and the best interpretative framework. Also the rationality of the Christian faith can be explained. This illustrates that not only personal faith, but also the witness of faith is in the path of fides quaerens intellectum. The Christian discourse starts from the heart and from that centre one seeks for accountability and clarification.

\section{A model for complementary apologetics}

After examining the differences and similarities between the several apologetic schools on the one hand and considering the motives for integration on the other, it is time to come to a proposal of such an integration of apologetic approaches. It is impossible to integrate the schools as such, because several schools have an exclusive view about themselves. Therefore in this approach for integration two decisions are taken. Firstly, only the positive characteristic perspectives of the several schools are integrated. Secondly, I propose not to speak about integration as such, but about complementary apologetics, because in this way the finer nuances of every school can be justified, whilst at the same time the strong points of every school can strengthen each other.
A common characteristic of every school is the conviction that faith is more than reason and that the personal knowledge of the triune God in the cross of Christ is not to be reached by reason. Also classical apologetics acknowledges that the use or reason with respect to the content of Christian faith is limited.

Therefore this common conviction forms the centre of a complementary apologetic model. In the centre of this model is the personal relationship with the crucified Christ: a relation that does not depend on arguments or proofs. The impression exists that fideists do not go further, however, this impression is generally speaking not true, because most fideists acknowledge that it is possible to speak in an understandable and reasonable way about the content of faith.

\section{Biblical perspective}

Given this possibility of accountability of the content of personal faith, one can orientate oneself towards another perspective in Christian apologetics, namely the broader unity of the biblical message, an aspect that is especially represented by revelational apologetics. A fideist will not be against the thesis of Plantinga and Wolterstorff (1983:55-56, 61-62) that faith is 'basic'. How does Van Til's approach relate to the accent on the personal relationship with Christ? However Van Til's revelational apologetics is focused on worldview, it can be argued that the personal relationship with Christ is implied (Boa \& Bowman 2006:240-243). Furthermore this apologetic is oriented towards the content of Christian faith in a trinitarian sense. There can be a difference in the understanding of Scripture. Presuppositionalists tend to harmonise Scripture more than fideists. Moreover, the distance between the person of Christ and the biblical witness of him is greater for some fideists than for presuppositionalists. It should be added that some fideists will see a contradiction between faith as a personal relation and faith in propositions. As long as one thinks in contradistinctions, integration is impossible. However, if fideists are able to deny the exclusive character of their approach and to connect the personal relation of Christ with the objective truth of the knowledge of God and Christ, there are enormous possibilities to incorporate central aspects of revelational apologetics in an integrative apologetics. Furthermore, the approach of this article pleads for the broader concept of complementary apologetics instead of a strict understanding of integrated apologetics.

The heart of the apologetic discourse lies in the hearts of Christians and their personal relationship with Christ. This is also the deepest motivation to reach unbelievers. In this complementary approach the Christian can start with a personal witness, but it is also possible to deal firstly with the presuppositions of faith, the worldview or the fundamental character of Christian faith. For the (extreme) fideist the last is not enough, but why should it not be possible to use this approach as a preparation for faith? 
Despite differences between fideism and revelational apologetic there are several interfaces between these schools (Boa \& Bowman 2006:520-521). Both schools underline the centre of the gospel and both approaches stress the gap between believers and unbelievers so that common ground is problematic. Supporters of both schools give witness of the full content of the trinitarian faith from the standpoint of faith instead of speaking in a neutral way towards faith. This means that the issue of God's ontology is not separated and isolated from the issue of soteriology.

At this point a dichotomy between apologetic approaches can be perceived. On the one hand the classical apologetics and evidentialism are seen, whilst on the other hand revelational apologetics and fideism are seen (Cowan 2000:375-381). In the apologetic conversation classic apologetics and evidentialism share the seeking of a starting point outside faith as the so-called common ground between believers and unbelievers. Revelational apologetics and fideists, however, are of the opinion that it is not allowed to seek this common ground and therefore they do not move towards faith in their discourse, but they witness from within the circle of faith.

\section{Rational perspective}

This observation makes it an exciting issue whether another perspective can be added to complementary apologetics in which on the one hand justice should be done to the central notions of fideism and revelational apologetics, and in which on the other hand, justice should be done to the central notions of classical apologetics and evidentialism.

In this context one should note that classical apologetics makes a distinction between two phases in the apologetic structure. It is not the intention of classical apologetics to deal in apologetics with the central content of the Christian faith. Classic apologists are conscious of the fact that reasonable arguments for faith can only be used as a preparation for the heart of the gospel in the message of cross and resurrection, because they do not pretend to be able to do any more than show the possibility and the reasonability of the existence of God. In that sense classical apologists are conscious that faith in God does not rest on proofs of God. Knowing the God of the proofs is not the same as knowing the personal God who revealed himself in the cross of Christ. Classical apologists use the proofs of God, however, to counter negative prejudices against a belief in God.

Revelational apologists and fideists criticise this apologetics because it misses assurance. A classical apologist will immediately agree. But here it must be remarked that the revelational apologist is not completely sure about the interpretation of every part of Scripture, especially concerning the worldview of history. This relativisation of the assurance of revelational apologetics cannot relativise the difference between these schools of apologetics. The difference is given with the assurance of faith itself and the possibility of human knowledge. Here an unbridgeable gap appears for the revelational apologist. Standing in the assurance and the reality of faith he cannot take the unbeliever in this reality. The conversation about the presuppositions and the reasonability of the Christian faith can create space for Christian faith, without reaching assurance. The absolute truth of God's reality cannot be transmitted to others. For the apologetic discourse this implies that the revelational apologist cannot do any more than defend the possibility of the Christian faith.

This means that there is enough reason for revelational apologetics and fideism to give space to the preparational work of classical apologetics. Given the distinction between magisterial and ministerial use of reason and the distinction between the knowledge of God in the gospel and the consciousness of God as Creator, there are no unbridgeable gaps.

A reproach from the perspective of revelational apologetics towards classic apologetics can also be that the cosmologicaland also the teleological - proof for the existence of God implies a reduction of the message of the gospel, because God is much more than the first beginning and the designer of the cosmos. From the point of view of revelational apologetics classical apologetics fails to show every aspect of Christian theism. This analysis is correct, but the question remains whether this critique is justified. Classical apologists do not pretend to present the complete message of the Word. They see their labour only as a small brick in the great building of the presentation of Christian faith.

\section{The factual perspective}

Within the context of a two phase apologetics the following step is that of the third perspective, namely the notion that is used in evidentialism concerning the observable of verifiable facts. One also notes that from the perspective of the revelational apologist or fideist the evidentialist does not come to the heart of the message. Despite this difference, the revelational apologist and the fideist have to agree that believers and unbelievers share the same ontological reality. This implies that there is a principal possibility to speak about the objective reality of the history of salvation. Believers and unbelievers speak from a different perspective, but the possibility of speaking about the same object cannot be denied at the outset.

Presuppositionalism opposes the argument that one can speak of historical facts without any presuppositions, but it cannot oppose the study of these facts as such. This insight gives a perspective for a relation between presuppositionalism and evidentialism. From his Christian presuppositions the Christian has the possibility to raise the historical proofs of Christ's resurrection or the proofs for the reliability of Scripture in the expectation that the Holy Spirit uses this research of historical facts as an instrument to convince the heart.

Perhaps this point is difficult for evidentialism, because evidentialism does not intend a two-step apologetics. Evidentialism can speak directly about the objective facts of Scripture, miracles, fulfilled prophecies and the resurrection of Christ to connect these facts with the central message of 
the gospel. If evidentialists can admit the distinction between historical faith and the personal relationship with Christ, the evidentialist can participate in complementary apologetics. Although this may be problematic for an individual evidentialist, it must be possible for evidentialism as such.

In this way it is also possible for evidentialism to give space for the presuppositionalist's question of the interpretative framework. This is also possible for evidentialism as such, because it belongs to the scientific approach to reflect on the method. This means that the question of the presuppositionalist can strengthen the case of complementary apologetics.

The totality of this investigation leads to a plea for complementary apologetic in which the centre is formed by personal faith in the gospel of the cross and in the acknowledgement that this is inaccessible for human understanding. This personal faith is embedded in the broader interpretative framework in which creation, fall and redemption become visible so that one can speak with the unbeliever. This position of faith is no hindrance to speak with the unbeliever about the rational arguments for the existence of God, nor is it a hindrance to testify of the objective facts of the history of salvation and to combine it with the interpretative framework. Standing in faith, faith seeks a better understanding of itself and accounts for faith to others.

\section{Conclusion}

In this article both the characteristics and the interfaces of the various apologetic schools have been investigated. Subsequently an investigation of the motives for integration followed, however, a concept of strict integration will be problematic. This leads to the development of a complementary concept in which not the schools as such can be integrated, but the characteristics of the several apologetic approaches can strengthen each other in a complementary way.

The foregoing investigation asks for an illustration of a complementary apologetics. This can be given by the reference to the resurrection of Christ. Believing apologists find the centre of their faith in the resurrected Christ, because the resurrection of Christ is not only the justification of Christ, but in communion with Him also the justification of the believer. Furthermore, the union with Christ implies that believers participate in his kingdom and eternal life, so that the complete life of the Christian is put in this perspective.

In the interaction with the unbelievers the believing apologists can witness of the meaning of Christ and his resurrection for their understanding of life. It is not unimaginable that the unbeliever reveals unbelief by fierce criticism on belief in a new world which is accomplished by a naked man on the cross. In the understanding of the unbeliever such a story is absurd. Faith in the resurrection of Christ is for the unbeliever rather a confirmation of the folly of the cross than a testimony of its truth.
Fideists are prepared on this criticism, because they understand this affliction from their own heart and they are deeply convinced that faith in the gospel of the cross is not attained by reasoning. Furthermore, they recognise the rejection of the cross from the first chapter of Paul's letter to the Corinthians (1 Cor 1:18-23). The apostle Paul proclaims - somewhat provocative - the centrality of the gospel of the cross with the remark that it is foolishness for the developed Greek. For fideists this is a reason to underline the transcendent character of the gospel that they personally cannot understand, but they witness the power of the gospel in their personal life. The gospel is so unimaginable for human reason that it must come from God, because nobody can invent this story.

From the presuppositional perspective it can be added in which interpretative framework Christ has to be understood, namely the framework of creation, sin and redemption. This apologist will ask his unbelieving interlocutors from which interpretative framework they think and live. In a qualified debate this interaction can lead to the acknowledgement that everybody thinks from his own interpretative framework of understanding, which interprets the world, the meaning of life and death, the origins and the future of history.

From the rational perspective of the classic apologist can be added that it is not unreasonable to presuppose that the Christian framework of understanding is true. The belief in a God who has created all things, the belief in the reality of sin and the belief in the redemption by God is coherent. At the background of this framework function concepts like trinity and incarnation, which are above human understanding. Nevertheless it can be argued that it is not unreasonable that God is another category than human beings. In this way the classic apologist defends and argues that the Christian understanding of reality is the best way to understand the coherence in reality (cf. Andrews 2012).

Also the evidentialists contribute to the debate. They can argue for the academic credibility of the resurrection of Christ. The combination of the empty tomb, the assurance of the witnesses of the resurrection and the rapid growth of Christianity in the time after the resurrection can be best explained from the acceptance of the bodily resurrection of Christ as a historical fact.

If the personal life style of apologists and their attitude in the mind of Christ underline their witness, the resurrection of Christ can be brought near to the unbeliever, so that prejudices disappear and the Holy Spirit convinces the unbeliever of the reality of the living Christ.

\section{Acknowledgements Competing interests}

The author declares that he has no financial or personal relationship(s) that may have inappropriately influenced him in writing this article. 


\section{References}

Andrews, E., 2012, Who made God: Searching for a theory of everything, Evangelical Press, Darlington.

Barnes, T.D., 1985, Tertullian: A literary and historical study, Clarendon, London.

Barth, K., 1960, Anselm: Fides quaerens intellectum, SCM, London.

Boa, K.D. \& Bowman, R.M., 2006, Faith has its reasons: Integrative approaches to defending the Christian faith, Paternoster, Milton Keynes.

Bray, G.L., 1979, Holiness and the will of God: Perspectives on the theology of Tertullian, Marshall, Morgan \& Scott, London.

Canlis, J., 2010, Calvin's ladder: A spiritual theology of ascent and ascension, Eerdmans, Grand Rapids.

Cowan, S.B., 2000, Five views on apologetics, Zondervan, Grand Rapids.

Craig, W.L., 2000, 'Classical apologetics', in S.B. Cowan (eds.), Five views on apologetics, pp. 25-55, Zondervan, Grand Rapids.

Daniel, R., 2010, This holy seed: Faith, hope and love in the early churches of North Africa, Tamarisk Publications, Chester.

Dawkins, R., 2006, The God delusion, Mariner, Boston.

Dunn, G.D., 2005, Tertullian, Routledge, London.

Edgar, W., 2003, Reasons of the heart, Presbyterian \& Reformed Publishing, Phillipsburg. Frame, J.M., 1987, The doctrine of the knowledge of God, Presbyterian \& Reformed Publishing, Phillipsburg.

Frame, J.M., 1994, Apologetics to the glory of God, Presbyterian \& Reformed Publishing, Phillipsburg.

Geisler, N.L., 1999, Baker encyclopedia of Christian apologetics, Baker, Grand Rapids.
Horton, M., 2007, Covenant and salvation: Union with Christ, Westminster John Knox, Louisville.

Lewis, G.R., 1976, Testing Christianity's truth claims: Approaches to Christian apologetics, Moody Press, Chicago.

Luther, M., Weimarer Ausgabe of Luthers Werke (= WA), 120 vols., 1883-2009.

Peters, J.R., 2009, The logic of the heart: Augustine, Pascal and the rationality of faith, Baker Academics, Grand Rapids.

Plantinga, A. \& Wolterstorff, N. (eds.), 1983, Faith and rationality: Reason and belief in God, University of Notre Dame Press, Notre Dame.

Ramm, B.L., 1962, Varieties of Christian apologetics, Baker, Grand Rapids.

Todd Billings, J., 2005, 'United to God through Christ: Assessing Calvin on the question of deification', Harvard Theological Journal 98(3), 315-334. http://dx.doi. org/10.1017/S0017816005000994

Todd Billings, J., 2008, Calvin, participation, and the gift: The activity of believers in union with Christ, Oxford University Press, Oxford.

Todd Billings, J., 2011, Union with Christ: Reframing theology and ministry for the church, Baker, Grand Rapids.

Van den Toren, B., 2011, Christian apologetics as cross-cultural dialogue, Clark, London.

Van Kooten, G.H., 2008, Paul's anthropology in context: The image of God, assimilation to God, and tripartite man in ancient Judaism, ancient philosophy and early Christianity, Mohr Siebeck, Tübingen.

Webster, J., 2007, 'Theologies of retrieval', in K. Tanner, I. Torrance \& J. Webster (eds.), The Oxford Handbook of systematic theology, pp. 58-599, Oxford University Press, New York.

Wyatt, P., 1996, Jesus Christ and creation in the theology of John Calvin, Pickwick Publications, Allison Park. 